УДК $811.1+81-112.4$

DOI https://doi.org/10.26661/2414-1135-2021-84-24

\title{
ПРАІНДОЄВРОПЕЙСЬКИЙ ПОЕТИКАЛЬНИЙ СПАДОК: МЕТОДОЛОГІЧНІ ЗАСНОВКИ КОРПУСНОГО ДОСЛІДЖЕННЯ ${ }^{1}$
}

\author{
Назаров Н. А. \\ кандидат філологічних наук, \\ старший науковий співробітник, докторант кафедри полоністики \\ Інститут філологї \\ Київського начіонального університету імені Тараса Шевченка \\ вул. Володимирська, 60, Київ, Україна \\ orcid.org/0000-0002-9051-7382 \\ nazarmia@gmail.com
}

\begin{abstract}
Ключові слова:
індоєвропейська поетика, корпусна лінгвістика, порівняльно-історичне мовознавство, етимологія, лінгвістична реконструкиія.
\end{abstract}

Індоєвропеїстика як галузь лінгвістики нині $є$ однією 3 найстаріших i найглибше угрунтованих галуззю. Ї̈ї беззаперечним здобутком є відкриття фонетичних законів і відповідностей між спорідненими мовами. Завдяки їм можливо реконструювати граматичний лад індоєвропейської прамови, набір іiі морфологічних формантів, словниковий склад, особливості синтаксису, просодикитощо. Усеце вкупідало можливістьреконструювати вищі рівні організації мовлення - поетичні кліше. У найдавніших текстах індоєвропейськими мовами (оди Піндара, епоси Гомера, гімни Рігведи й Авести, хетські тексти тощо) є сталі вислови, які складаються 3 етимологічно споріднених слів. Тому вже в середині 19 століття стало зрозуміло, що деякі фрази індоєвропейської поетичної (ритуальної) мови так само могли зберегтися в дочірніх фольклорних (а згодом - поетичних і літературних) традиціях. Таку галузь студій започаткував німецький філолог Адальберт Кун у 1853 році, коли показав, що і в давньогрецьких, і у ведійських текстах є стале поєднання двох етимологічно споріднених слів - «нев’януча слава». Відкриття наступної спільноіндоєвропейської формули («колесо сонця») належить цьому ж лінгвісту. Натепер відомо понад 50 подібних фраз. Це - релікти спільноіндоєвропейської поетичної мови. Вони зберегли найголовніші ідеологеми й міфологеми індоєвропейських еліт: «швидкі коні», «коні й мужі», «подавач благ» (про божество), «(бог) / небо безсмертне», «(бог) / небо довговічне», «(бог) / небо-батько», «донька (бога) / неба», «(божественна) / небесна ранкова зоря», «з поганою / хорошою славою», «слава мужів», «велика слава», «широка слава» й інші. Класичний і донині компендіум “Dichtung und Dichtersprache in indogermanischer Zeit” був виданий Р. Шміттом у 1967 році. 3 того часу процедура реконструкції спільноіндоєвропейських поетичних формул суттєво не змінилася: дослідник читає тексти давніми мовами, покладаючись тільки на свою пам'ять, знаходить у них послідовності етимологічно споріднених слів і припускає, що вони відтворюють поєднання, властиві ще індоєвропейському етапові. Стаття теоретично обгрунтовує можливість застосування корпусних підходів до виявлення спільноіндоєвропейських поетичних кліше, що на практиці вже було частково здійснено в попередніх публікаціях автора.

\footnotetext{
${ }^{1}$ Дослідження виконано в рамках проєкту 2020.02/0241 «Еколінгвістичні модуси дискурсивного простору України в європейському полікультурному континуумі», що фінансується Національним фондом досліджень України.
} 


\title{
COMMON INDO-EUROPEAN POETIC HERITAGE: METHODOLOGICAL PRINCIPLES OF CORPUS RESEARCH
}

\author{
Nazarov N. A. \\ Candidate of Philological Sciences, Senior Researcher, \\ Postdoctoral Student at the Department of Polish Studies \\ Taras Shevchenko National University of Kyiv \\ Volodymyrska str., 60, Kyiv, Ukraine \\ orcid.org/0000-0002-9051-7382 \\ nazarmia@gmail.com
}

Key words: Indo-European poetics, corpus linguistics, comparative-historical linguistics, etymology, linguistic reconstruction.

\begin{abstract}
Indo-European studies as a branch of linguistics is one of the oldest and most soundly grounded. Its main achievement consists in phonetic laws and phonetic correspondences between related languages. Due to these laws, it is possible to reconstruct the grammatical structure of Indo-European language, its set of morphological formants, vocabulary, features of syntax, prosody, etc. All this made it possible to reconstruct the higher levels of speech organization poetic cliches. In the oldest texts of Indo-European languages (Pindaric odes, Homeric epics, hymns of the Rigveda and Avesta, Hittite texts, etc.), there are expressions, which consist of etymologically related words. Therefore, in the middle of the 19th century it became clear that some phrases of the Indo-European poetic (ritual) language could also be preserved in the daughter folklore (and later - poetic and literary) traditions. This field of study was started by the German philologist Adalbert Kuhn in 1853, when he showed that in both ancient Greek and Vedic texts there is a stable combination of two etymologically related words - "unfading glory". The discovery of the next common Indo-European formula ("wheel of the sun") belongs to the same linguist. Today, more than 50 such phrases are known. These are remnants of the common Indo-European poetic language. They have preserved the most important ideologemes and mythologemes of Indo-European elites: "fast horses", "horses and men", "giver of goods" (about a deity), "immortal sky, "long-lived sky", "sky-father", "daughter of heaven", "celestial morning star", "with bad / good glory", "glory of men", "great glory", "wide glory" and others. The classic compendium "Dichtung und Dichtersprache in indogermanischer Zeit" was published by R. Schmitt in 1967. Since then, the procedure for reconstructing common Indo-European poetic formulas has not changed significantly: the researcher reads texts in ancient languages and, relying only on his memory, finds in them sequences of etymologically related words, and suggests that they reflect combinations that existed already at the IndoEuropean stage. The present article theoretically substantiates the possibility of applying corpus approaches to the identification of common Indo-European poetic clichés, which on practice has already been partially implemented in previous publications of the author.
\end{abstract}

Постановка проблеми. Одним із головних положень порівняльно-історичного дослідження фольклорної поетики може бути теза О.С. Мельничука про реальність реконструкції: реконструйовані праформи (а в нашому випадку - поетичні кліше й формули) дійсно існували в конкретній прамові, яка мала своїх носіїв. Точна ідентифікація суспільної групи носіїв є спільним завданням археології, генетики й лінгвістики. Результати аналізу поетичних кліше можуть слугувати додатковим джерелом для такої ідентифікації.
Метою статті $€$ теоретичне обгрунтування процедури порівняльно-історичного дослідження поетичних кліше слов'янських та інших індоєвропейських фольклорів, окреслення етапів обробки матеріалу й способів верифікації отриманих результатів за допомогою корпусного підходу.

Новизна зумовлена тим, що в науковій літературі не існує ні експліцитно сформульованих рекомендацій і принципів реконструкції поетикального спадку індоєвропейців, ні тим паче - їх теоретичного обгрунтування. I це не зважаючи на 
те, що сама реконструкція індоєвропейської поетики проводиться із середини 19 століття.

Зв'язок із попередньою лінгвістичною традицією. «Індоєвропейський» часто вживається в літературі замість «праіндоєвропейський», аби не переобтяжувати текст. Попередні вживання терміна «лінгвістична реконструкція» теж зафіксовані в науковій літературі (наприклад, назва збірника «Сравнительно-историческое изучения языков разных семей. Теория лингвистической реконструкции». Москва, 1988 рік). «Індоєвропейська поетика» як комплекс формальних засобів фольклорних текстів спільноіндоєвропейського періоду (без уточнення) так само є усталеним висловом. Приклади попереднього вживання [1].

Виклад основного змісту. Реконструкція фонетичного, просодичного, метричного, морфологічного, лексичного й синтаксичного рівнів поетичної мови спільноіндоєвропейського періоду передбачає оновлення, збагачення процедур самої реконструкції.

Усі засоби поетичної мови для зручності скорочено названо поетикою, тобто сукупністю виражальних засобів тексту. Реконструкція передбачає дослідження за допомогою порівняльно-історичного методу типових фольклорних текстів різних індоєвропейських народів, передусім балтів, слов'ян, давніх греків, римлян, давніх індійців, хетів, і використання свідчень інших традицій для уточнення отриманих результатів.

Етимологічна інтерпретація генетично споріднених елементів текстів у дочірніх традиціях дозволяє виокремити клішовані вислови-формули, які з великою імовірністю існували в прамові [2]. Такі формули мають спільні фонетичні, просодичні й метричні властивості, вони можуть поєднуватися в короткі фрази, еквівалентні простому реченню.

Отже, реконструкція поетичної мови індоєвропейців передбачає дослідження всіх рівнів мови, від фонетики до синтаксису. Оскільки реконструкція фрагментів пратекстів оперує одиницями більшими, ніж слово, це відкриває ширші можливості для реконструкції синтаксичної будови праіндоєвропейського простого речення та докладнішого 3'ясування лексичної реалізації його членів [3; 4]. Нашим інноваційним підходом є дослідження тісної взаємодії метрики й синтаксису поетичного тексту, що й дозволяє уточнювати позиції різних поетичних формул у простому реченні.

Результатом такого дослідження є реконструкція тезаурусу головних клішованих висловів індоєвропейської поетичної мови (з їх рефлексами в балто-слов'янських фольклорах, що раніше не були достатньо викладені в науковій літературі), визначення їхніх метричних i синтаксичних властивостей, ролі в композиції більших текстів, і врешті - інтерпретація соціокультурного контексту, який такі формули відбивали (вірування, норми звичаєвого права, соціальна організація тощо). Частково завдання вже було зроблено в наших попередніх публікаціях [5; 6].

Поетична мова - це підсистема мови взагалі як комунікативної системи, отже, реконструкція індоєвропейської поетичної мови базується на реконструкції індоєвропейської мови як цілісності. Станом натепер усі рівні праіндоєвропейської мови реконструйовані досить детально [7-10], хоч i нині залишаються певні спірні питання, які не впливають на загальне розуміння системи індоєвропейської мови на момент іiі розпаду на окремі гілки.

Таким чином, до наших безпосередніх завдань не входить сама по собі реконструкція всіх рівнів праіндоєвропейської мови, адже це вже зроблено в численних часткових та узагальнюючих працях. Однак викласти сучасний стан реконструкції індоєвропейської прамови нам необхідно, тому що саме вона і є тією матеріальною базою, тією множиною елементів, на якій і реалізується індоєвропейська поетична мова, інакше кажучи, мова в мові. Тому необхідно навести відомості про фонетичний, просодичний, морфологічний, лексичний і синтаксичний рівні реконструйованої прамови $з$ огляду на те, як ці свідчення надалі будуть використані для реконструкції індоєвропейської поетики.

Так, індоєвропейський лексикон грунтовано опрацьований у низці робіт, що містять суцільний словниковий склад індоєвропейської прамови. Такими є словник Ю. Покорни (гніздовий словник, організований за індоєвропейським етимоном), друга частина праці Іванова-Гамкрелідзе (організована за тематичним принципом, містить розгляд дериватів у дочірніх мовах), праця Меллорі (тематичний принцип, подано етимологічні обгрунтування). Нарешті, досі найповнішим і найгрунтовнішим лишається словник Ю. Покорни, i тому його й донині використовують як матеріал для укладання електронних словників (https:// liberalarts.utexas.edu/lrc/resources/ielex.php). Саме цей електронний варіант словника Покорни ми й взяли за основу для свого систематичного опрацювання індоєвропейського лексикону. Однак наша тематична класифікація докорінно відрізняється як від запропонованої на сайті https:// liberalarts.utexas.edu, так і від тієї, яку ми знаходимо в книзі Мелорі. Оскільки процедурно етимологічна реконструкція словникового складу індоєвропейської (далі - IЄ) прамови має тільки незначну кількість спірних питань, то доцільно розглядати реконструйований лексикон як множину, яку можна досліджувати як самодостатню систему. Нас будуть цікавити системні типи 
зв'язків, які мають значення для творення поетичної мови: парадигматичні й синтагматичні зв'язки, явища синонімії / антонімії, гіперонімії / гіпонімії, синонімічна розробленість певних тематичних груп, наявність омонімів і спільнокореневих слів (між якими на IЄ рівні складно провести розрізнення), а також явища фонетичної подібності, які могли бути використані для гри слів та інших фонетичних засобів поетичної виразності. Саме $з$ такого підходу IС лексикон, наскільки нам відомо, суцільною вибіркою не був проаналізований (за винятком явищ омонімії в праслов'янській [11] і прагерманській [12] мовах зі звертанням до I€ стану).

Дослідження індоєвропейської поетики має значні напрацювання, що узагальнені в кількох оглядових працях $[13 ; 14 ; 2 ; 1 ; 15 ; 16]$. Докладна бібліографія 3 аналізом літератури, що з'явилася після праці Шмідта 1967 року [13], наведена в [15]. Попри значний часовий проміжок, що пройшов між першою та останньою працею (близько 50 років), вони виконані в руслі однієї філологічної традиції, що тягнеться ще 319 століття. Цей філологічний метод можна описати таким чином. У давніх текстах дочірніх індоєвропейських традицій шляхом суцільного перегляду знаходять одиничні словосполучення чи повторювані формули, які складаються з етимологічно споріднених слів, і для такої мінімальної послідовності наводиться IЄ етимон, що і є IЄ поетичною формулою. Надалі формула цілком може бути підтверджена свідченнями порівняльної міфології, етнології чи археології. Результати (досить значні) такої реконструкції вже викладено в перелічених працях, і ми їх теж узагальнимо, перш ніж перейти до своїх подальших досліджень. У процесі узагальнення результатів нас буде цікавити: як лексика, що входить до поетичних формул, зіставляється 3 усією системою IЄ лексики? Які тематичні групи стають основними для поетичних формул? Які парадигматичні й синтагматичні зв'язки актуалізує лексика з формул (iї, власне, і можна назвати суто поетичною лексикою)? Які синтаксичні особливості вже виявлених формул?

На наступному етапі ми пропонуємо власну методологію виявлення ІС поетичних формул, що використовує підходи корпусної лінгвістики. Наш корпусний підхід жодним чином не має заступити попередній, класичний філологічний підхід, а має тільки доповнити його, ставши ще одним, незалежним джерелом для реконструкції IЄ поетики. Підстави для нашого підходу такі.

Формульний характер поетичної мови індоєвропейців випливає як із генетичних, так і 3 типологічних свідчень. Генетичні свідчення - усі відомі найдавніші індоєвропейські поетичні тексти мають формульну структуру. Типологічно - усі архаїчні традиції усного слова (фольклору) використовують формульні кліше для творення мікрой макротекстів. Отже, IЄ поетика, безсумнівно, мала такий же формульний характер.

Звідси випливає підхід до реконструкції мікрой макротекстів IЄ традиції, що полягає передусім в реконструкції набору сталих кліше, формул.

Формула в розумінні, запровадженому в класичній філології та фольклористиці А. Лордом i М. Перрі [17], - це слово чи словосполучення, яке вживається в певному місці поетичної / пісенної фрази / рядка. Найстабільнішими місцями є початок і кінець фрази, де концентруються ключові слова-формули, які $є$ гніздами мереж подібних формул.

Грегорі Надь [18], проаналізувавши словосполучення нев'януча слава в давньогрецькому гомерівському корпусі й у давньоіндійському епосі, виявив, що формула зберігає не тільки сталість (вживається саме як формула), а й певне розміщення в поетичному рядку й акцентуаційну парадигму. Із чого випливає, що й інші формули, як уже виявлені, так і ще не виявлені, можуть мати такі ж властивості.

Левінтон [19] показав, що в сербському епосі й билинах клас слів, що можуть вживатися в клаузулах рядків, складається здебільшого 3 етимологічно споріднених слів або ж (у рідкісних випадках втрати одного зі споріднених слів) зі слів, що $\epsilon$ семантичним заміщенням етимологічно спорідненого елемента.

Свідчення етномузикології також підтверджують, що саме остання позиція пісенного рядка i $\epsilon$ місцем, де починає з'являтися регуляція ритму, поки решта рядка може мати довільне чергування маркованих i немаркованих складів. Саме до таких узагальнень дійшли й індоєвропеїсти, розглядаючи вихідний стан IЄ метрики [20]. Із чого й випливає особливість нашого методу реконструкції ІС поетики.

У дочірніх IC традиціях за допомогою корпусного підходу ми визначаємо клас клаузульних, тобто ключових, слів, що формують гнізда споріднених між собою формул. У кожній із традицій такий клас налічує не більше кількох сотень слів. При чому важливо вказати, що виявлені раніше класичними філологічними методами формули здебільшого вживаються саме в клаузулах. А це дозволяє розглядати корпусний підхід до виявлення спільно-ІЄ поетичних формул як природне продовження класичного філологічного методу, однак уже на новому етапі розвитку інструментів аналізу тексту.

Але наш аналіз суттєво відрізняється від прийнятого в західноєвропейській і північноамериканській індоєвропеїстиці підходу, коли за основу реконструкції беруться тільки давньогрецька й 
давньоіндійська традиція зі спорадичним зверненням до інших. У нашому аналізі 3 якомога більшою повнотою відтворені свідчення всіх слов'янських епічних традицій, а також латиських народних пісень міфологічного змісту. Послідовне корпусне зіставлення слов'янського матеріалу 3 давньогрецьким, давньоіндійським, латиським i матеріалом інших традицій дозволило виявити не лише нові рефлекси вже відомих формул, а й встановити нові формули, які не були виявлені шляхом класичного філологічного аналізу вужчого кола традицій. У такому й полягає інноваційність нашої роботи.

У зв'язку з тим, що важливі спостереження щодо спільностей клаузульного класу слів базується на етномузикологічних джерелах, нам довелося розробити методологію залучення свідчень етномузикології до досліджень із порівняльно-історичного мовознавства. Так, нами вперше у світовій індоєвропеїстиці була запропонована спроба етномузикологічної та лінгвістичної реконструкції IЄ музичної ідіоми, яка $є$ незалежним джерелом для перевірки лінгвістичних свідчень, а також зв'язків старої акутової інтонації в праслов'янській мові з особливостями виконання (явище цезури в словах).

Висновки. Згідно 3 головною особливістю лінгвістичної реконструкції - іiі частковістю - ні традиційний філологічний метод пошуку IС поетичних формул, ні запропонований нами корпусний метод не можуть реконструювати всі можливі поетичні кліше. Однак поєднання обох підходів дозволить покрити більшу кількість етимологічно значущих збігів у дочірніх традиціях і покласти початок реконструкції IЄ поетики саме як системного тезауруса формул, пов'язаних між собою синтагматичними й парадигматичними зв'язками.

Результати генетичної реконструкції видаються тим обгрунтованішими, якщо для них $є$ підтвердження типологічного характеру, засновані на матеріалі неспоріднених віддалених у часі чи просторі традицій. Саме тому системність IЄ поетики зіставляється 3 особливостями систем давньокитайської, давньояпонської, давньотюркської та австронезійської поетики, які й можуть слугувати джерелами для пошуку певних загальних рис поетики традиційного фольклору, дозволивши на їхньому тлі виявити риси, специфічні саме для IЄ поетики.

Перспективи подальших досліджень. Подальшими кроками для втілення запропонованої програми досліджень є видання порівняльного словника поетичних формул слов'янських епосів на індоєвропейському тлі, монографічного дослідження про індоєвропейську поетику з активнішим залученням балтських і слов'янських фольклорів, а також вірменського й осетинського фольклорів, і врешті - видання популярного вступу до індоєвропейських студій, розрахованого як на фахового читача-гуманітарія, так і на ширший загал читачів, не байдужих до давньої історії. Нарешті, на основі перелічених видань можна буде організувати викладання вступу до індоєвропеїстики на базі одного з державних університетів України. Така серія заходів повинна допомогти індоєвропейським студіям ввійти до кола інтересів лінгвістів і ширшої громадськості.

\section{ЛITЕРАТУРА}

1. Watkins C. How to kill a dragon. New York; Oxford : Oxford University Press, 1995. 640 p.

2. Гамкрелидзе Т.В., Иванов В.В. Индоевропейский язык и индоевропейцы. Тбилиси : Издательство Тбилисского университета, 1984. 1409 с.

3. Степанов Ю.С. Индоевропейское предложение. Москва : URSS, 2017. 248 с.

4. Lehman W. Proto-Indo-European syntax. University of Texas Press, 1974. 278 p.

5. Nazarov N.A. Reconstruction of the common Slavic thesaurus of epic poetic formulas: the corpus approach. New Philology. 2021. No. 2 (81). P. 24-31. DOI: https:// doi.org/10.26661/2414-1135-2021-81-2-3.

6. Nazarov N. Selected entries from the etymological dictionary of common Slavic poetic formulas against the Indo-European background. Contemporary Studies in Foreign Philology. 2021. Vol. 19. No. 1. P. 99-108. DOI: https://doi.org/ 10.32782/2617-3921.2021.19.99-108.

7. Мейе А. Введение в сравнительное изучение индоевропейских языков. Москва ; Ленинград : Социально-экономическое издательство, 1938.512 с.

8. Одри Ж. Индоевропейский язык. Новое в зарубежной лингвистике: Bыn. XXI. Новое в современной индоевропеистике. Москва : Прогресс, 1988. С. 24-121.

9. Савченко А.Н. Сравнительная грамматика индоевропейских языков. Москва : Высшая школа, 1974. $412 \mathrm{c.}$

10. Szemerenyi O. Introduction to Indo-European Linguistics. Oxford University Press, 1996. $352 \mathrm{p}$.

11. Аникин А.Е. Опыт семантического анализа праславянской омонимии на индоевропейском фоне. Новосибирск : Наука, 1988. 126 с.

12. Левицкий В.В. Этимологический словарь германских языков. Винница : Нова книга, 2010. T. $1-2.616+368 \mathrm{c}$.

13. Schmitt R. Dichtung und Dichtersprache in indogermanischer Zeit. Wiesbaden, 1967. 375 S.

14. Durante M. Sulla preistoria della tradizione poetica greca: Risultanze della comparazione indoeuropea. Roma : Ediz. del'Ateneo, 1976. 222 p. 
15. Campanile Ricerche di cultura poetica indoeuropea. Pisa : Giardini, 1978. 128 p.

16. West M.L. Indo-European poetry and myth. Oxford : Oxford University Press, 2007. 525 p.

17. Lord A. The Singer of Tales. New York : Athenaeum, 2000. $307 \mathrm{p}$.

18. Надь Г. Греческая мифология и поэтика. Москва : Прогресс, 2002. 433 с.

19. Левинтон Г.А. Лексика славянских эпических традиций и проблема реконструкции праславянского текста. Текст: семантика и структура. Москва : Наука, 1983. С. 152-172.

20. Nazarov N. Indo-European Musical Idiom and Indo-European Ethnogenesis. 20 p. (in print).

\section{REFERENCES}

1. Watkins, C. (1995). How to kill a dragon. New York; Oxford : Oxford University Press.

2. Gamkrelidze, T., Ivanov, V. (1984) Indoevropeyskiy yazyk $i$ indoevropeytsy. Tbilisi: Izdatelstvo Tbilisskogo universiteta. [IndoEuropean language and Indo-Europeans].

3. Stepanov, Yu. (2017) Indoevropeyskoe predlozhenie. Moskva : URSS. [Indo-European sentence].

4. Lehman, W. (1974) Proto-Indo-European syntax. University of Texas Press.

5. Nazarov, N. (2021) Reconstruction of the common Slavic thesaurus of epic poetic formulas: the corpus approach. New Philology 2 (81), pp. 24-31. https://doi.org/10.26661/2414-1135-2021-81-2-3

6. Nazarov, N. (2021) Selected entries from the etymological dictionary of common Slavic poetic formulas against the Indo-European background. Contemporary Studies in Foreign Philology Vol. 19 No. 1. pp. 99-108. https:// doi.org/10.32782/2617-3921.2021.19.99-108

7. Meye, A. (1938) Vvedenie $v$ sravnitelnoe izuchenie indoevropeyskikh yazykov. Moskva; Leningrad: Sotsialno-ekonomicheskoe izdatelstvo. [Introduction to comparative study of IndoEuropean languages].

8. Odri, Zh. (1988) Indoevropeyskiy yazyk. Novoe $v$ zarubezhnoy lingvistike: Vyp. XXI. Novoe
$\mathrm{V}$ sovremennoy indoevropeistike. Moskva: Progress. pp. 24-121. [The Indo-European language].

9. Savchenko, A. (1974) Sravnitelnaya grammatika indoevropeyskikh yazykov. Moskva: Vysshaya shkola. [Comparative grammar of Indo-European languages].

10. Szemerenyi, O. (1996) Introduction to IndoEuropean Linguistics. Oxford University Press.

11. Anikin, A. (1988) Opyt semanticheskogo analiza praslavyanskoy omonimii na indoevropeyskom fone. Novosibirsk: Nauka. [Attempt of semantic analysis of homonyms against Indo-European background].

12. Levitskiy, V. (2010) Etimologicheskiy slovar germanskikh yazykov. Vinnitsa : Nova kniga. T. 1-2. [Etymological dictionary of German languages].

13. Schmitt, R. (1967). Dichtung und Dichtersprache in indogermanischer Zeit. Wiesbaden : Otto Harasowitz.

14. Durante, M. (1971). Sulla preistoria della tradizione poetica greca: Risultanze della comparazione indoeuropea. T. 1, 2. Roma, 1971. T. 2. 1976.

15. Campanile, E. (1978) Ricerche di cultura poetica indoeuropea. Pisa: Giardini.

16. West, M. (2007). Indo-European poetry and myth. Oxford: Oxford University Press.

17. Lord, A. The Singer of Tales. New York : Athenaeum.

18. Nagy, G. (2002) Greek mythology and poetics [Grecheskaya mifologiya i poetika]. Moskva: Progres.

19. Levinton, G. (1983). Vocabulary of Slavic epic traditions and a problem of the Common Slavic text reconstruction [Leksika slavjanskich epicheskich tradicij i problema rekostrukciji praslavjanskogo teksta]. In: T. Tsyvjan, ed. Tekst: Semantika i struktura, pp. 152-172. Moskva : Nauka.

20. Nazarov, N. Indo-European Musical Idiom and Indo-European Ethnogenesis (in print). 